Chirurgia (2020) 115: 798-806

No. 6, November - December

Copyright $\odot$ Celsius

http://dx.doi.org/10.21614/chirurgia.115.6.798

\title{
Severe Bleeding Complications Resulting in Death Following Anticoagulant Treatment in COVID-19 Surgical Patients
}

\author{
Cristian Botezatu $^{1,2}$, Marius Petruțescu ${ }^{1 *}$, Marian Forminte ${ }^{1}$, Bogdan Stelian Mastalier Manolescu ${ }^{1,2}$ \\ ${ }^{1}$ General Surgery Clinic, Colentina Clinical Hospital, Bucharest, Romania \\ 2“Carol Davila” University of Medicine and Pharmacy, Bucharest, Romania
}

*Corresponding author: Marius Petruțescu, MD

"Carol Davila" University of Medicine and Pharmacy

Colentina Clinical Hospital

General Surgery Clinic

Bucharest, Romania

E-mail: cristi_botezatu2001@yahoo.com

\section{Rezumat \\ Complicatii hemoragice severe soldate cu deces consecutive tratamentului anticoagulant la pacienți chirurgicali COVID-19}

Formarea microtrombilor în circulația pulmonară reprezintă unul dintre principalele mecanisme fiziopatologice responsabile de evolutia nefavorabilă respiratorie a pacienților COVID-19. Terapia anticoagulantă cu heparine cu greutate moleculară mică (HGMM) reprezintă un pilon principal al tratamentului. Uneori, însă, HGMM produc complicații severe care pot fi soldate cu decese. Studiu retrospectiv, descriptiv, care analizează 3 cazuri de hemoragii severe urmate de deces la pacienți COVID-19 anticoagulați în doze terapeutice cu HGMM în luna septembrie în unitățile spitaliceşti de proveniență. Pacienții au prezentat hematoame ale muşchilor drepți abdominali şi hemoperitoneu (2 cazuri), respectiv hematom al muşchilor fesieri stângi (1 caz). Au fost operați cei 2 pacienți cu hematom al muşchilor drepți abdominali. Decesul a survenit între 1-4 zile de la internare.

Cuvinte cheie: hemoragie severă, tratament anticoagulant, infecție COVID-19

\section{Abstract}

Microthrombi formation in the pulmonary circulation is one of the main pathophysiological mechanisms responsible for the unfavorable respiratory evolution of $\mathrm{CoViD}-19$ patients. Low 
molecular weight heparin (LMWH) anticoagulant therapy is a major pillar of treatment. But sometimes LMWH causes severe complications that can result in death. This is a retrospective, descriptive study, covering September 2020 and presenting 3 cases of severe hemorrhages followed by death in COVID-19 anticoagulated patients in therapeutic doses with LMWH in the hospital units of origin. Patients had hematomas of the rectus abdominal muscles and hemoperitoneum ( 2 cases) respectively hematoma of left gluteal muscles ( 1 case). The 2 patients with hematoma of rectus abdominal muscles were operated. The death occurred between 1-4 days after hospitalization.

Key words: severe haemorrhage, anticoagulant treatment, COVID-19 infection

\section{Introduction}

Until the beginning of the XXIst century, coronaviruses (HCoV-NL63, HCoV-229E, HCoV$\mathrm{OC} 43$ and $\mathrm{HKU}$ ) were responsible for common cold in humans. But, in 2002 the SARS-CoV was discovered, followed by the MERS-CoV, in 2013. This two new viruses were proved to determine a severe respiratory syndrome and represented extremely pathogenic virus types for humans, because of their high capacity to adapt to the host, especially regarding their increased connection for their receptor, thus determining critically infections $(1,2)$.

In December 2019, an outbreak of pneumonia of unknown etiology was reported in Hubei province, Wuhan municipality, China. In January 2020, the etiologic agent was isolated and described by the Chinese government as a new coronavirus (SARS-CoV-2 or 2019-nCoV) (3-6). The Chinese Scientists identified a new severe acute respiratory syndrome that determined this new disease, which, in order to differentiate from past similar pathologies, they named it "coronavirus-19" (COVID-19) $(7,8)$.

SARS-CoV2 is one of seven human-infecting coronaviruses identified so far. It is a single strand positive sense RNA virus (+) ssRNA belonging to the $B$-coronavirus lineage $\mathrm{B}(3,5)$. The symptomatology of COVID-19 varies from asymptomatic patients or patients with mild symptoms to a very severe clinical aspect, that can even evolve to the patients' death. Generally, the symptomatology includes cough, fever, and shortness of breath. In some patients, fatigue, alteration of general state, respiratory difficulties, muscle pain, sore throat, loss of taste and/or smelling capacitywere observed (9).

Among other pathophysiological modifications, SARS-CoV-2 induces a state of hypercoagulability and, while mortality in COVID19 can be largely attributed to hypoxemia secondary to acute respiratory distress syndrome (ARDS), there is growing suspicion that thromboembolic events could also be contributing to the overall picture (10-12).

The hypercoagulable state in COVID-19 is still under investigation, but some mechanisms could lead to it: disseminated intravascular coagulation (DIC), properties of the virus itself, antiphospholipid syndrome, activation of the complement cascade, and endothelial dysfunction induced by the infection (13-16). The citokine storm or the macrophage activation syndrome are likely to determine a disproportionate inflammatory reaction that can increase the mortality in SARS-CoV-2. McGonagle et al. asserts that the tropism of SARS-CoV-2 towards angiotensin-converting enzyme 2 (ACE2), mostly present in type II pneumocytes, leads to an inflammatory cascade causing a generalized pulmonary hypercoagulable state (17). The secondary lymphohistiocytosis triggers expression of tissue factor in the endothelial cells, macrophages, and neutrophils, inducing activation of the coagulation cascade (18). Beyond the hypercoagulable state this generates, there has been proved that thrombin production and high quantities of 
fibrin deposited at the bronchoalveolar level are linked to the severe form of pneumonia. Given the MAS-like disease of COVID-19 pneumonia and the associated procoagulable state, guided therapy with anti-cytokine therapy and anticoagulation is an interesting possibility (19).

Thrombotic events affect approximately $16 \%$ of hospitalized patients with COVID-19. A retrospective study demonstrated that mechanically ventilated patients had lower in-hospital mortality when anticoagulated vs those who did not receive anticoagulation. Postmortem examination of pulmonary vessels has demonstrated thrombosis with microangiopathy. These and other observations have led to recommendations of anticoagulation for patients with COVID-19 to prevent venous and arterial thromboembolic events. For example, a new treatment protocol, MATH+ (fig. 1), endorsed by the Front Line COVID-19 Critical Care Alliance for all hospitalized patients with COVID-19 who develop respiratory distress, includes heparin to treat hypercoagulability. Although anticoagulation protects against thrombosis, a recent study revealed that 33 of 755 patients with COVID-19 developed intracranial hemorrhage. Most of these cases represented hemorrhagic transformation of ischemic

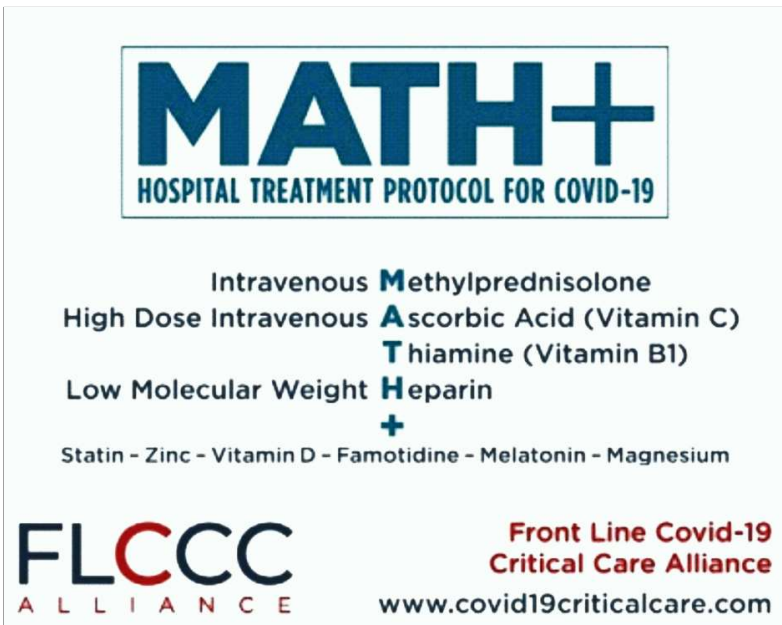

Figure 1. Paul Marik. Eastern Virginia Medical School (EVMS) Critical Care COVID-19 Management Protocol

https://www.evms.edu/media/evms_public/departments/ internal_medicine/EVMS_Critical_Care_COVID-19_Protocol.pdf stroke. Eighteen of the patients had received prophylactic anticoagulation for an elevated D-dimer level and concern for prothrombotic state. Although preventing thrombotic events, such as pulmonary embolism and ischemic strokes, is important, the risk for fatal hemorrhagic stroke emphasizes the need for further study before prophylactic therapeutic anticoagulation of all patients with COVID-19 with severe respiratory compromise becomes routine practice (20).

Adam Flaczyk and al. reviewedseveral schemes, from different societies, regarding the treatment of coagulation disorders in COVID-19 patients (21): the Centers for Disease Control and Prevention (CDC) (22), International Society on Thrombosis and Haemostasis interim guidance (ISTH-IG) (23), American Society of Hematology (ASH) $(24,25)$, American College of Chest Physicians (ACCP) (26), Scientific and Standardization Committee of ISTH (SCC-ISTH) (27), Anticoagulation Forum (ACF) (28), and American College of Cardiology (ACC) (29). The ACF pleads, on one hand, for high anticoagulant doses in those patients which present a severe form of the disease(enoxaparin $40 \mathrm{mg}$ twice daily or heparin 7500 unit/dose three times daily) and, on the other hand,they prefer using only prophylactic anticoagulant dosesin patients with non-critical disease.The SCC-ISTH recommends using intermediate low molecular weight heparin doses (LMWH) for high risk critically ill patients, as well as in non-critically ill patients, during their hospitalization.The same SCC-ISTH urges that the anticoagulation treatment should be adapted according to the body weight (an increasing of $50 \%$ in dose in case of obesity), advanced thrombocytopenia, or poor renal function. The ACC sustain the idea that, despite the fact that, at the time being, there aren't enough studies to plead for using anticoagulants as a standard treatment, in intermediate or therapeutic doses, an intermediate intensity (i.e., enoxaparin $1 \mathrm{mg} / \mathrm{kg} /$ day, enoxaparin $40 \mathrm{mg}$ twice daily, unfractionated heparin [UFH] with target partial prothrombin time [PTT] 50-70) or therapeutic anticoagulation seems 
to be reasonable (21-29).

Regarding the prophylactic anticoagulation, many of the societies recommend using once daily anticoagulants. ASH prefers the use of LMWH instead of UFH in order to lower the exposure, excepting the cases in which the hemorrhagic risk is higher than the risk of thrombosis. The use of oral anticoagulants as a routine treatment is not recommended by ant of the associations mentioned above, because of their disadvantages: pharmacodynamics may be influenced by a pre-existing liver or renal malfunction, their cost is higher, they have longer half-live, and, in some cases, there are hospitals which don't have the possibility to provide a reversal agent in case of overdose. Regarding the anticoagulation in therapeutic regimen, the CDC agrees to use the same doses as in patients without COVID-19, the $\mathrm{ACF}$ and $\mathrm{ACCP}$, in order to lower the medical personal exposure, choose LMWH over UFH, the ACC points out that, due to its advantages represented by lower risk of drug to drug interaction with other therapies needed in patients with COVID-19, respectively the possibility to be temporarily stopped, parenteral anticoagulation with UFH may be preferred, leaving the LMWH for the COVID-19 patients in which a high-risk bleeding invasive procedure is unlikely to be needed. In case of patients with acute bleeding or advanced thrombocytopenia, the majority of the above societies agree that the anticoagulation regimen should be hold. In case of COVID-19 patients who use anticoagulation therapy as a chronic one and are suspected or confirmed with disseminated intravascular coagulation with acute haemorrhage, the ACC recommends adjusting the anticoagulants doses, or even briefly interrupting the anticoagulation treatment, in order to reduce the risk of bleeding. Unless the risk of thrombosis is very high, lowering the anticoagulation doses is indicated (21-29).

Girish N. Nadkarni et al. conducted a study on a group of 4389 patients with COVID-19 and compared with no anticoagulation group $(n=1,530 ; 34.9 \%)$, the therapeutic anticoagulation group $(n=900 ; 20.5 \%)$ and the prophylactic anticoagulation one $(n=1,959$; $44.6 \%)$ were associated with lower in-hospital mortality. 89 patients (2\%) had major bleeding adjudicated by clinician review, with 27 of 900 (3.0\%) on therapeutic, 33 of $1,959(1.7 \%)$ on prophylactic, and 29 of $1,530(1.9 \%)$ on no anticoagulation. The proportion of patients with bleeding events after initiation of anticoagulation treatment was highest in patients on therapeutic anticoagulation (27 of 900; 3.0\%) compared with patients on prophylactic anticoagulation (33 of 1,$959 ; 1.7 \%$ ) and no anti-coagulation (29 of 1,530; 1.9\%) (30).

\section{Clinical Cases}

In this context, we present a retrospective, descriptive study that includes 3 cases of severe hemorrhages followed by death in COVID-19 anticoagulated patients, which were transferred in September to "Colentina" Surgical Department from another COVID-19 Hospital, where they received anticoagulation (LMWH) in therapeutic doses.

The first case was a female patient, M.A., aged 69, who was urgently transferred from "Victor Babes" Hospital after an abdominal trauma produced by falling from the same level. The clinical exam at the admission in our Surgical Department revealed the following: pallor, somnolence, abdominal pain, systolic blood pressure $110 \mathrm{mmHg}$, pulse rate 90 $\mathrm{b} / \mathrm{min}$, oxygen saturation $94 \%$ (patient with oxygen mask $10 \mathrm{l} / \mathrm{min}$ ). The abdominal CT revealed hematoma of the abdominal wall, haemoperitoneum, active haemorrhage (Figs. 2, 3, 4, 5). The laboratory tests indicated: $\mathrm{Hb} 4,8 \mathrm{~g} / \mathrm{dl}$, Ht 14,10\%, WBC 30040/mmc, NEU 27560/mmc, PLT 57000/ul, fibrinogen 131 $\mathrm{mg} / \mathrm{dl}$, INR 2,29, APTT 32,5 s, SARS COV 2 positive, CK 966 UI/l, CK-MB 54,4 UI/l, Ddimer 6,59 ug/ml, feritin $8564 \mathrm{ng} / \mathrm{ml}$, Interleukin-6 $1531 \mathrm{pg} / \mathrm{ml}$, PRO-BNP 1680 $\mathrm{pg} / \mathrm{ml}$, procalcitonin $0,79 \mathrm{ng} / \mathrm{ml}$, PCR 1,55 $\mathrm{mg} / \mathrm{l}$, Troponin $\mathrm{T} 139,8 \mathrm{pg} / \mathrm{ml}$, uric acid 9 $\mathrm{mg} / \mathrm{dl}$, albumin $2,33 \mathrm{~g} / \mathrm{dl}$, amylase $218 \mathrm{UI} / \mathrm{l}$, creatinine $3,04 \mathrm{mg} / \mathrm{dl}$, cholesterol 104,9 mg/dl, alkaline phosphatase $58 \mathrm{UI} / 1$, glucose 213,7 $\mathrm{mg} / \mathrm{dl}$, potassium $3,53 \mathrm{mg} / \mathrm{dl}$, proteins 3,87 


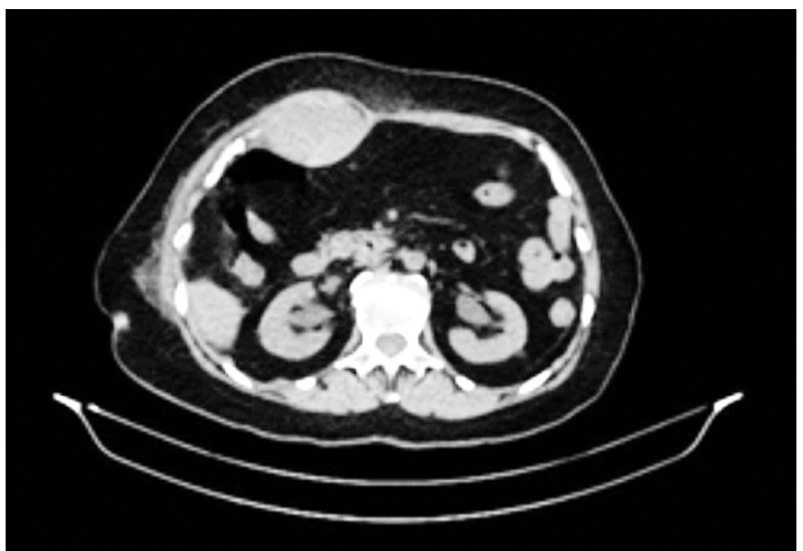

Figure 2. Abdominal wall hematoma (transversal view)

g/dl, sodium $156 \mathrm{mmol} / \mathrm{l}$, TGO 1125,6 UI/l TGP $1660 \mathrm{UI} / \mathrm{l}$, urea 151,9 mg/dl. Concomitant with the re-equilibration treatment and blood transfusions, the patient was urged to the OR. Intraoperatively, we discovered rectus abdominal muscles hematoma, haemoperitoneum with non-coagulated blood, no major bleeding source, but with multiple blood extravasations through the muscle fibers. The evacuation of

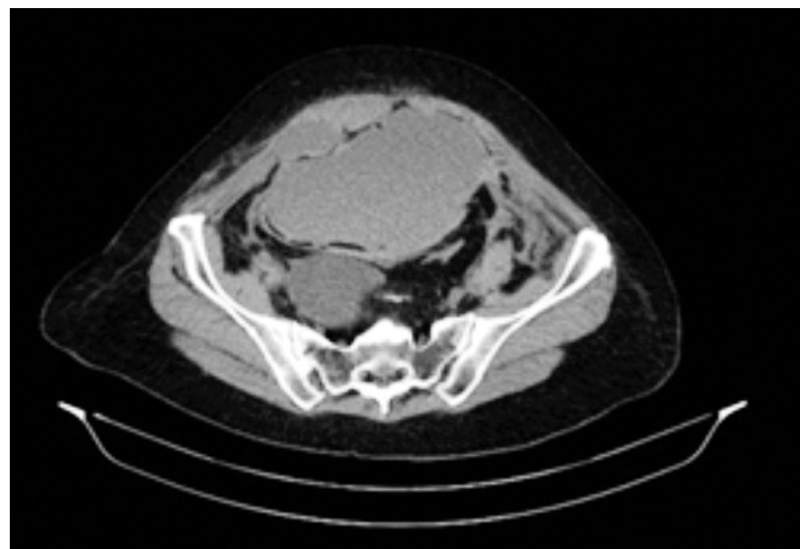

Figure 3. Haemoperitoneum (transversal view)

the hematoma and the haemoperitoneum, lavage, hemostasis, application of hemostatic sponges/powders and drainage were performed. Postoperatively, we continued to administer blood transfusions, fresh frozen plasma and antihaemorrhagics. Despite all this measures, the patient's condition continued to be unfavorable. An abdominal ultrasound was performed and it revealed the

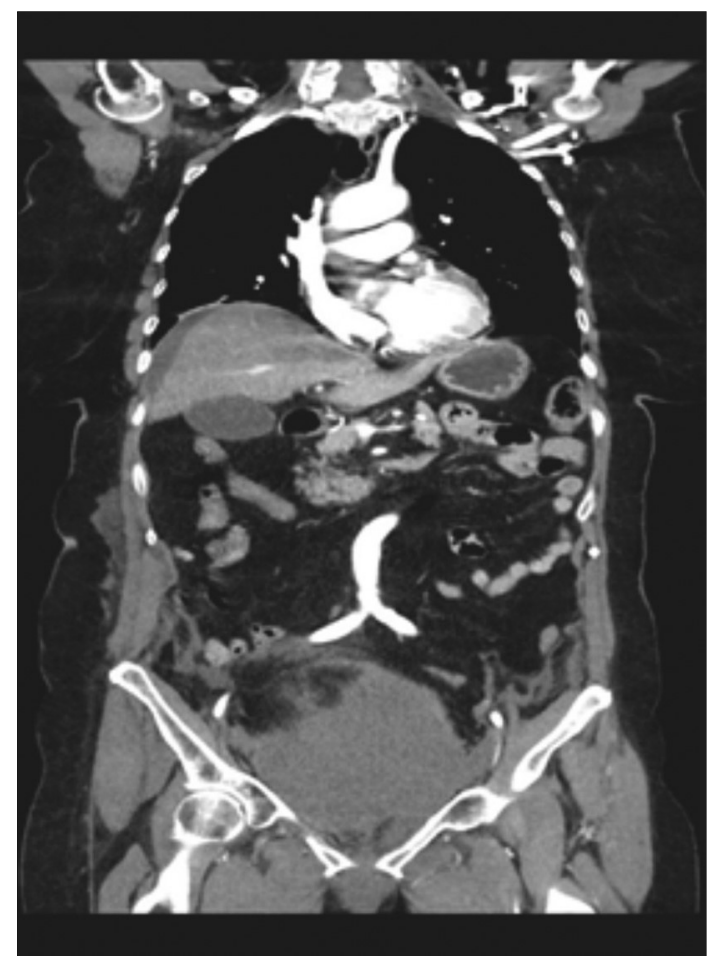

Figure 4. Haemoperitoneum (sagital view)

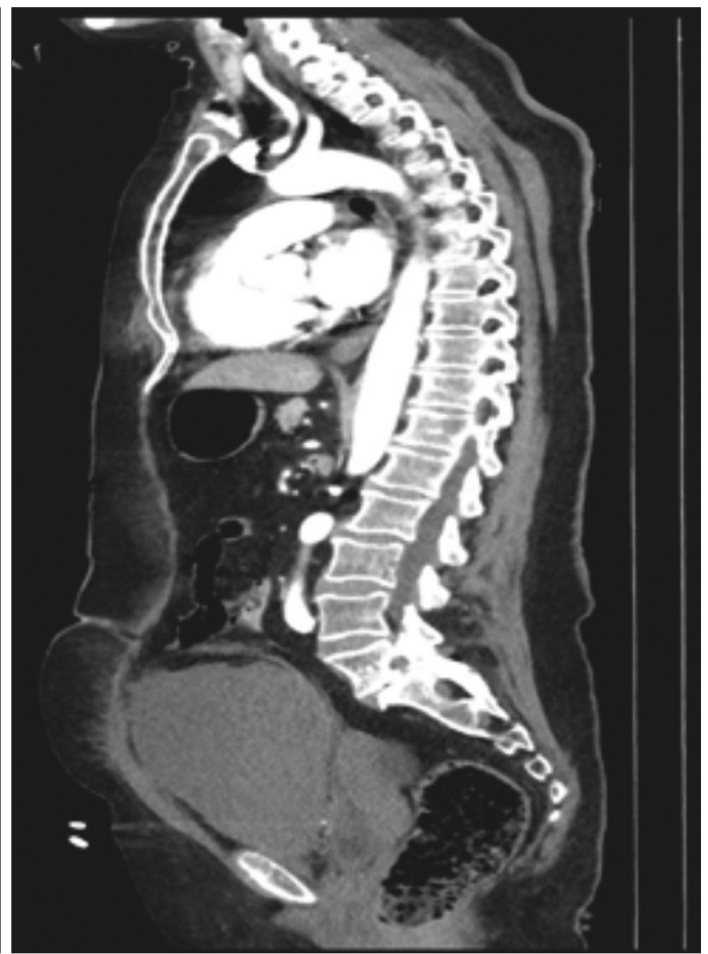

Figure 5. Haemoperitoneum (lateral view) 


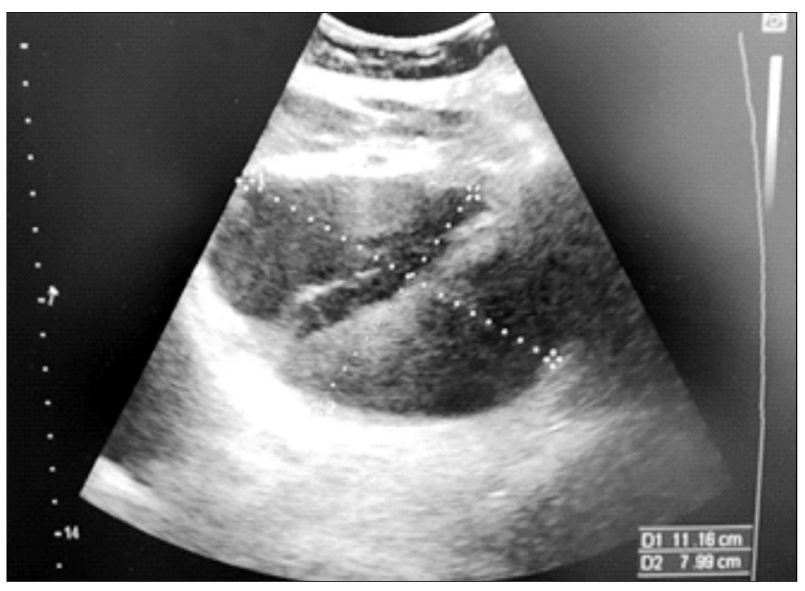

Figure 6. Postoperatively pelvic ultrasound

recurrence of the haemoperitoneum (Fig. 6). The patient was once again operated, 24 hours after the first intervention, the same surgical steps being performed. Short time after the reintervention, the patient developed MODS and exitus occurred at 48 hours.

The second case was a male patient, T.D., aged 52, also transferred in emergency conditions from "Victor Babes" Hospital, where he suffered a left gluteal area trauma after falling. He was also being treated with high doses of LMWH (Fragmin 15000 IU/24 h) during the hospitalization. Clinical exam at the admission in our Surgical Department: altered general state, low blood pressure $(53 / 36 \mathrm{mmHg})$, tachycardia $(114 \mathrm{~b} / \mathrm{min})$, left gluteal hematoma (Fig. 7 ), oliguria. Laboratory tests: $\mathrm{Hb} 4,9$ g/dl, Ht 18 \%, WBC $15970 / \mathrm{mmc}$, NEU $14370 / \mathrm{mmc}$, PLT 99000 /ul, fibrinogen

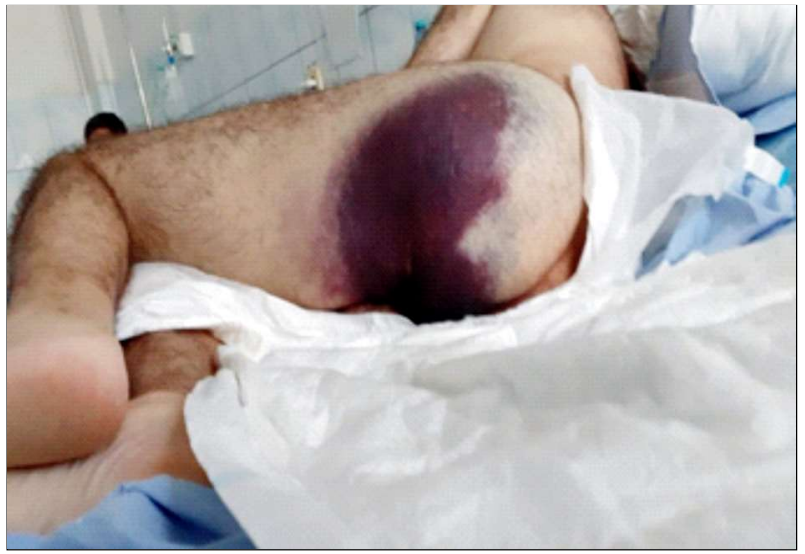

Figure 7. Left gluteal hematoma
$162 \mathrm{mg} / \mathrm{dl}$, INR 1,78, APTT 50,70 s, SARS COV 2 positive, CK 633 UI/l, CK-MB 37,6 UI/l, Ddimer $0,27 \mathrm{ug} / \mathrm{ml}$, feritin $1808 \mathrm{ng} / \mathrm{ml}$, Interleukin-6 782,9 pg/ml, PRO-BNP 1138 $\mathrm{pg} / \mathrm{ml}$, procalcitonin $0,19 \mathrm{ng} / \mathrm{ml}$, PCR 1,49 $\mathrm{mg} / \mathrm{l}$, Troponin $\mathrm{T} 68,28 \mathrm{pg} / \mathrm{ml}$, uric acid 10 $\mathrm{mg} / \mathrm{dl}$, albumin $3,12 \mathrm{~g} / \mathrm{dl}$, Ca total $7,55 \mathrm{mg} / \mathrm{dl}$, creatinine $2,92 \mathrm{mg} / \mathrm{dl}$, glucose $549 \mathrm{mg} / \mathrm{dl}, \mathrm{LDH}$ $471 \mathrm{UI} / \mathrm{l}$, potassium $6,71 \mathrm{mg} / \mathrm{dl}$, protein 4,93 $\mathrm{g} / \mathrm{dl}$, TGO UI/l, TGP UI/l, uree $243 \mathrm{mg} / \mathrm{dl}$. The left gluteal area ultrasonography that was performed, with Doppler included, showed a large hematoma, but without active bleeding source. The left hip and left femur Rx didn't identify a bone fracture. The thorax CT revealed images specific for COVID pneumonia, $58 \%$ of the lungs being affected. We didn't have the possibility to perform an angiography-CT. The patient benefited from blood transfusion, administration of fresh frozen plasma, antihaemorrhagics, noradrenalin, oxygen therapy, local ice application, fluid and electrolyte re-equilibration. Although, at the beginning, the patient's state seemed to improve, after 24 hours from the admission, he became unstable and needed to be transferred in the ICU, where, after another 24 hours, he developed cardiac arrest that didn't respond to the resuscitation maneuvers, the patient's exitus being declared.

The last case we present is a female patient, D.A., aged 77 . Like the other two patients, she was an emergency transfer from the same COVID Hospital after being diagnosed, through abdominal $\mathrm{CT}$, with hematoma of the rectus abdominal muscles and hemoperitoneum, the difference being that she didn't suffer any trauma. She was also being treated in the initial hospital with large doses of LMWH. The clinical exam at the admission in our Surgical Department revealed acute abdomen, hypotension under vasopressor support. Laboratory analysis: $\mathrm{Hb} 4,9 \mathrm{~g} / \mathrm{dl}$, WBC $30510 / \mathrm{mmc}$, NEU 27580/mmc, PLT 45000/mmc, fibrinogen 40 $\mathrm{mg} / \mathrm{dl}$, INR 5,59, APTT 85,5 s, SARS COV 2 positive, CK 105 UI/l, CK-MB 47,9 UI/1, Ddimer $1,06 \mathrm{ug} / \mathrm{ml}$, feritin $34806 \mathrm{ng} / \mathrm{ml}$, Interleukin-6 1115 pg/ml, PRO-BNP 1360 
$\mathrm{pg} / \mathrm{ml}$, procalcitonin $0,59 \mathrm{ng} / \mathrm{ml}$, PCR 1,02 $\mathrm{mg} / \mathrm{l}$, Troponin $\mathrm{T} 149,5 \mathrm{pg} / \mathrm{ml}$, uric acid 7,3 $\mathrm{mg} / \mathrm{dl}$, albumin 0,65 g/dl, Ca total 8,88 mg/dl, cholesterol 25,6 mg/dl, creatinine 1,92 mg/dl, proteine $1,16 \mathrm{~g} / \mathrm{dl}$, TGO $245 \mathrm{UI} / \mathrm{l}$, TGP UI/l, urea $134 \mathrm{mg} / \mathrm{dl}$. The patient was urged into the OR and intraoperatively, hemoperitoneum, rupture of the lower third of the rectus abdominal muscle and hematoma in the prevesical space were confirmed. Evacuation of the hemoperitoneum and the prevesical hematoma, lavage, multiple peritoneal drainage and application of Mikulicz hemostatic mesh were performed. Concomitant, the patient received blood transfution, fresh frozen plasma, antihaemorrhagics, noradrenalin and oxygen therapy. Despite all the treatment measures, surgical and non-surgical, the patient's evolution was quickly unfavorable, thus she developed cardiac arrest 9 hours after the surgical intervention. Resuscitation maneuvers were applied, but without response, the patient being declared dead.

\section{Discussions}

Most of the studies in the literature showed the benefic effect of the anticoagulation treatment in COVID patients, taking in consideration the fact that SARS-COV-2 determines, through multiple mechanisms, a coagulopathy that is favored by an advanced inflammation syndrome, which includes endothelial dysfunction, impaired blood-flow, platelet activation, and increased coagulability, thus determining a higher risk of thrombotic complications that could be represented by deep venous thrombosis (DVT), pulmonary embolism (PE), and microvasculature thrombosis $(13,31,32,33)$.

On the other hand, the risk of using large doses of anticoagulant (therapeutic dose), should be taken in consideration, whereas there are studies which rise the problem regarding the main side effect of this treatment, namely the hemorrhage. For example, Siddhant Dogra et al. or Alexandra Kvernland et al. published articles in which they observed a high incidence of hemorrhagic stroke in patients that received therapeutic doses of anticoagulant $(34,35)$.

Another important aspect is the one related to the type of the anticoagulant that is used. If we take in consideration using heparin, for example, we should pay attention to the fact that heparin has a $10-15 \%$ risk of significant bleeding and that many risk factors that may increase the odds of an acute haemorrhage, such as advanced age, critical form of the disease, trauma or surgeryrecent case history, cardiopulmonary resuscitation, longer period spent in hospital, leukopenia and thrombocytopenia, are frequently encounteredin patients with COVID-19 $(36,37)$. LMWHs have some advantages compared to UFH, namely: decreasing the medical staff exposure, conserving the personal protective equipment, the once daily administration in prophylactic therapy reduces missed doses cases, decreasing the laboratory monitoring in case of therapeutic treatment (21).

In his study, Girish N. Nadkarni et al. observed that among patients on a single therapeutic agent, bleeding rates were higher in those on low molecular weight heparin (LMWH) compared with direct oral anticoagulants (DOACs) (2.6\% vs. $1.3 \%$, respectively), and among those on a single prophylactic agent, bleeding rates were higher in those on unfractionated heparin (UFH) compared with LMWH ( $1.7 \%$ vs. $0.7 \%$, respectively) (30).

In our Surgical Department, over the years, we observed differences regarding the risk of bleeding even between the different types of LMWHs, so that we always preferred Enoxaparin over Dalteparin or Nadroparin, especially when we were talking about therapeutic doses of anticoagulant therapy. That's why, even in COVID patients, that we, as COVID-Support Hospital, have been treating since March 2020, we continued to use only Enoxaparin as anticoagulant, both in prophylactic and therapeutic doses.

All three cases presented in this article were treated during their initial hospitalization with therapeutic doses of Dalteparin, and the patients developed life-threatening haemorrhages after minimal traumas or even 
without a trauma. All three patients had low fibrinogen values, that leading to the idea that the probable mechanism for their bleedings was disseminated intravascular coagulation. We didn't find in any patient a major vessel as the source of the bleeding, instead, the haemorrhages were diffuse. Intraoperatively, we discovered clots in large quantities that could lead to consumptive coagulopathy, which irreversibly aggravate the evolution.

\section{Conclusions}

Although our study cannot be very eloquent, due to the low number of patients analyzed, our aim is to trigger an alarm signal in order to avoid the increase of number of such cases. We plead for the usage of prophylactic doses of anticoagulant in COVID patients, instead of therapeutic ones, when there are no other indications, and for choosing Enoxaparin as the preferred LMWH, due to its increased safety profile.

\section{Conflict of Interests}

The authors declare no conflict of interests.

\section{References}

1. Cui J, Li F, Shi Z-L. Origin and evolution of pathogenic coronaviruses. Nat Rev Microbiol. 2019;17:181-192.

2. Li W, Zhang C, Sui J, Kuhn JH, Moore MJ, Luo S, et al. Receptor and viral determinants of SARS-coronavirus adaptation to human ACE2. EMBO J. 2005;24:1634-1643.

3. Singh A, Shaikh A, Singh R, Singh AK. COVID-19: from bench to bed side. Diabetes Metab Syndr. 2020;14:277-281.

4. Pan Y, Li X, Yang G, Fan J, Tang Y, Zhao J, et al. Serological immunochromatographic approach in diagnosis with SARS-CoV-2 infected COVID-19 patients. J Infect. 2020;81:e28-e32.

5. D'Amico F, Baumgart DC, Danese S, Peyrin-Biroulet L. Diarrhea during COVID-19 infection: pathogenesis, epidemiology, prevention and management. Clin Gastroenterol Hepatol. 2020;18(8):1663-1672. Epub 2020 Apr 8.

6. Rothan HA, Byrareddy SN. The epidemiology and pathogenesis of coronavirus disease (COVID-19) outbreak. J Autoimmun. 2020; 109:102433. Epub 2020 Feb 26.

7. Yuen K-S, Ye Z-W, Fung S-Y, Chan C-P, Jin D-Y. SARS-CoV-2 and COVID-19: The most important research questions. Cell Biosci. 2020 Mar 16:10:40. eCollection 2020.

8. Schett G, Sticherling M, Neurath MF. COVID-19: risk for cytokine targeting in chronic inflammatory diseases? Nat Rev Immunol. 2020;20(5):271-272.

9. Lovato A, de Filippis C, Marioni G. Upper airway symptoms in coronavirus disease 2019 (COVID-19). Am J Otolaryngol. May-Jun 2020;41(3):102474. Epub 2020 Apr 4.
10. Tang N, Li D, Wang X, Sun Z. Abnormal coagulation parameters are associated with poor prognosis in patients with novel coronavirus pneumonia. J Thromb Haemost. 2020;18(4):844-847.

11. Bikdeli B, Madhavan MV, Jimenez D, Chuich T, Dreyfus I, Driggin E, et al. COVID-19 and thrombotic or thromboembolic disease: implications for prevention, antithrombotic therapy, and follow-up. J Am Coll Cardiol. April 2020;S0735109720350087.

12. Cui S, Chen S, Li X, Liu S, Wang F. Prevalence of venous thromboembolism in patients with severe novel coronavirus pneumonia. J Thromb Haemost. 2020;18(6):1421-1424. Epub 2020 May 6.

13. Zhang $\mathrm{Y}$, Xiao $M$, Zhang $S$, Xia $P$, Cao $W$, Jiang $W$, et al. Coagulopathy and antiphospholipid antibodies in patients with Covid-19. N Engl J Med. 2020; 382(17):e38. Epub 2020 Apr 8.

14. Uthman IW, Gharavi AE. Viral infections and antiphospholipid antibodies. Semin Arthritis Rheum. 2002;31(4):256-263.

15. Li T, Lu H, Zhang W. Clinical observation and management of COVID-19 patients. Emerging Microbes \& Infections. 2020;9(1): 687-90. 10.1080/22221751.2020.1741327.

16. Campbell CM, Kahwash R. Will complement inhibition be the new target in treating COVID-19 related systemic thrombosis?. Circulation. 2020;141(22):1739-1741. Epub 2020 Apr 9.

17. Hoffmann M, Kleine-Weber H, Schroeder S, Krüger N, Herrler T, Erichsen S, et al. SARS-CoV-2 cell entry depends on ACE2 and TMPRSS2 and is blocked by a clinically proven protease inhibitor. Cell. 2020;181(2):271-280.e8. Epub 2020 Mar 5.

18. Giannis D, Ziogas IA, Gianni P. Coagulation disorders in coronavirus infected patients: COVID-19, SARS-CoV-1. MERS-CoV and lessons from the past. J Clin Virol. 2020;127:104362. Epub 2020 Apr 9

19. Rico-Mesa JS, Rosas D, Ahmadian-Tehrani A, White A, Anderson AS, Chilton R. The role of anticoagulation in COVID-19-induced hypercoagulability. Curr Cardiol Rep. 2022; 22(7):53. Published online 2020 Jun 17.

20. Wilner AN. Anticoagulation for COVID-19: more harm than good? Available from https://www.medscape.com/viewarticle/938013

21. Flaczyk A, Rosovsky RP, Reed CT, Bankhead-Kendall BK, Bittner EA, Chang MG. Comparison of published guidelines for management of coagulopathy and thrombosis in critically ill patients with COVID 19: implications for clinical practice and future investigations. Crit Care. 2020 Sep 16;24(1):559.

22. National Institutes of Health. Coronavirus disease 2019 (COVID19) treatment guidelines. 2020.

23. Thachil J, Tang N, Gando S, Falanga A, Cattaneo M, Levi M, et al. ISTH interim guidance on recognition and management of coagulopathy in COVID-19. J Thromb Haemost. 2020;18(5):10231026. Epub 2020 Apr 27.

24. American Society of Hematology. COVID-19 and VTE/anticoagulation: frequently asked questions. 2020 June 23.

25. American Society of Hematology. COVID-19 and coagulopathy: frequently asked questions. June 23, 20202020.

26. Moores LK, Tritschler T, Brosnahan S, Carrier M, Collen JF, Doerschug $\mathrm{K}$, et al. Prevention, diagnosis and treatment of venous thromboembolism in patients with COVID-19: CHEST Guideline and Expert Panel Report. Chest. 2020; 158(3):1143-63. Epub 2020 Jun 2.

27. Spyropoulos AC, Levy JH, Ageno W, Connors JM, Hunt BJ, Iba T, et al. Scientific and Standardization Committee communication: clinical guidance on the diagnosis, prevention and treatment of venous thromboembolism in hospitalized patients with COVID-19. J Thromb Haemost. 2020;18(8):1859-65.

28. Barnes GD, Burnett A, Allen A, Blumenstein M, Clark NP, Cuker A, et al. Thromboembolism and anticoagulant therapy during the COVID-19 pandemic: interim clinical guidance from the anticoagulation forum. J Thromb Thrombolysis. 2020;50(1):72-81.

29. Bikdeli B, Madhavan MV, Jimenez D, Chuich T, Dreyfus I, Driggin E, et al. COVID-19 and thrombotic or thromboembolic disease: implications for prevention, antithrombotic therapy, and follow-up: 
JACC state-of-the-art review. J Am Coll Cardiol. 2020;75(23): 2950-2973.

30. Nadkarni GN, Lala A, Bagiella E, Chang HL, Moreno PR, Pujadas E, et al. Anticoagulation, Bleeding, Mortality, and Pathology in Hospitalized Patients With COVID-19. J Am Coll Cardiol. 2020; 76(16):1815-1826. Published online 2020 Aug 26.

31. Danzi GB, Loffi M, Galeazzi G, Gherbesi E. Acute pulmonary embolism and COVID-19 pneumonia: a random association? Eur Heart J. 2020;41(19):1858.

32. Martinelli I, Ferrazzi E, Ciavarella A, Erra R, Iurlaro E, Ossola M, et al. Pulmonary embolism in a young pregnant woman with COVID19. Thromb Res. 2020; 191:36-37. Epub 2020 Apr 20.

33. Al-Samkari H, Karp Leaf RS, Dzik WH, Carlson JC T, Fogerty AE, Waheed A, et al. COVID and coagulation: bleeding and thrombotic manifestations of SARS-CoV2 infection. Blood. 2020;136(4): 489-500.
34. Dogra S, Jain R, Cao M, Bilaloglu S, Zagzag D, Hochman S, et al. Hemorrhagic stroke and anticoagulation in COVID-19. J Stroke Cerebrovasc Dis. 2020; 29(8): 104984. Epub 2020 May 23.

35. Kvernland A, Kumar A, Yaghi S, Raz E, Frontera J, Lewis A, et al. Anticoagulation use and Hemorrhagic Stroke in SARS-CoV-2 Patients Treated at a New York Healthcare System. Neurocrit Care. 2020 Aug 24;1-12. Online ahead of print.

36. Cossette B, Pelletier MĖ, Carrier N, Turgeon M, Leclair C, Charron $P$, et al. Evaluation of bleeding risk in patients exposed to therapeutic unfractionated or low-molecular-weight heparin: a cohort study in the context of a quality improvement initiative. Ann Pharmacother. 2010;44(6):994-1002. Epub 2010 May 4.

37. Nieuwenhuis HK, Albada J, Banga JD, Sixma JJ. Identification of risk factors for bleeding during treatment of acute venous thromboembolism with heparin or low molecular weight heparin. Blood. 1991;78(9):2337-43. 